Katarzyna Sipurzyńska-Rudnicka

Uniwersytet Ekonomiczny we Wrocławiu

\title{
Przyszłość demograficzna Polski a rynek pracy
}

DOI: $10.19195 / 1643-0328.24 .8$

Słowa kluczowe: demografia, rynek pracy, potencjalne zasoby pracy, Polska, prognozy

\section{Wprowadzenie}

Zjawiska i procesy demograficzne stanowią istotne uwarunkowanie zmian zachodzących na rynku pracy. Wywierają one wpływ zwłaszcza na stronę podażową tego rynku, określając bezpośrednio rozmiary i strukturę dostępnych oraz możliwych do wykorzystania w procesach gospodarczych zasobów ludzkich. Nadmierne, w stosunku do potrzeb gospodarczych, zasoby czynnika ludzkiego prowadzić mogą do rozwoju bezrobocia i wielu negatywnych skutków ekonomicznych, społecznych i politycznych związanych z tym zjawiskiem. Z kolei niskie zasoby tego czynnika wywołać mogą inny typ nierównowagi na rynku pracy w postaci deficytu siły roboczej, a w konsekwencji trudności $\mathrm{w}$ zaspokajaniu potrzeb kadrowych zakładów pracy i osłabienie rozwoju gospodarczego.

Spośród zmian demograficznych najistotniejsze znaczenie dla rynku pracy mają zmiany dotyczące rozmiarów i struktury potencjalnych zasobów pracy, tj. populacji osób w wieku produkcyjnym. Populacja ta obejmuje ludność umownie uznaną za zdolną do pracy na podstawie cech demograficznych, w tym głównie określonego wieku, w którym wykazuje ona największą sprawność zawodową i aktywność na rynku pracy. W praktyce społeczno-gospodarczej ustalenie granic tego wieku nie jest sprawą prostą ze względu na złożoność wpływających na to czynników i uwarunkowań (demograficznych, ekonomicznych, społeczno-kulturowych, prawnych, politycznych), w tym z powodu odmiennych poglądów i oczekiwań reprezentowanych w tym zakresie przez różne podmioty działające na rynku pracy (pracowników i ich rodziny, związki zawodowe, pracodawców, organizacje pracodawców oraz państwo). W rezultacie stosowane w praktyce granice wieku produkcyjnego miały dotychczas umowny charakter, przyjmowały różny zakres i były przedmiotem ogólnospołecznych dyskusji, a nawet walki politycznej ${ }^{1}$. W latach

${ }^{1}$ Różnice stanowisk w tym zakresie ilustrują zmiany ustawowe dotyczące wieku przejścia na emeryturę (co określa tym samym górną granicę wieku produkcyjnego), wprowadzane w Polsce przez kolejne partie 
1990-2015 w badaniach polskiej statystyki publicznej przyjmowano najczęściej za wiek produkcyjny przedział 18-59 lat dla kobiet oraz 18-64 lat dla mężczyzn². Należy jednak dodać, że w statystyce międzynarodowej, np. w opracowaniach Europejskiego Urzędu Statystycznego (EUROSTAT), za granice tego wieku przyjmuje się 15-64 lata ${ }^{3}$.

Znajomość przewidywanych zmian w zakresie rozmiarów i struktury potencjalnych zasobów pracy ma istotne znaczenie dla wszystkich podmiotów działających na rynku pracy, pozwala bowiem na lepsze przygotowanie się do funkcjonowania $\mathrm{w}$ określonej sytuacji (typie nierównowagi) na tym rynku. Prognozowane uwarunkowania demograficzne powinny być uwzględnione zwłaszcza w różnych obszarach działań państwa związanych bezpośrednio lub pośrednio z rynkiem pracy i jego otoczeniem. Dotyczy to między innymi polityki rynku pracy (np. w zakresie określania strategii na rzecz promocji zatrudnienia i ograniczania bezrobocia, $w$ tym dostosowywania programów rynku pracy do cech i potrzeb podaży pracy), polityki migracyjnej (np. w zakresie rozwiązań wpływających na rozmiary imigracji zastępczej obcych zasobów pracy czy też emigracji lub reemigracji rodzimych zasobów pracy), polityki edukacyjnej (np. w zakresie dostosowywania szkolnych i pozaszkolnych systemów edukacyjnych do uwarunkowań demograficznych i potrzeb gospodarki), polityki zabezpieczenia społecznego pracowników i ich rodzin (m.in. w zakresie dostosowania do zmian demograficznych, rozwiązań w zakresie ubezpieczeń emerytalno-rentowych czy też rozwiązań w systemach opieki zdrowotnej).

Celem niniejszego opracowania jest określenie przewidywanych zmian w zakresie rozmiarów i struktury potencjalnych zasobów pracy w Polsce w okresie do 2050 r., a także zabranie głosu w dyskusji nad ich potencjalnym wpływem na rynek pracy i gospodarkę.

\section{Przewidywane zmiany rozmiarów i struktury potencjalnych zasobów pracy}

W przygotowanym przez Główny Urząd Statystyczny opracowaniu Prognoza Ludności na lata 2014-2050 dane dotyczące przewidywanych rozmiarów i struktury potencjalnych zasobów pracy określone zostały dla dwóch wariantów wieku produkcyjnego ${ }^{4}$ :

— wariant I - uwzględnia tradycyjne granice wieku produkcyjnego, wynoszące 1859 lat dla kobiet oraz 18-64 lat dla mężczyzn;

- wariant II — uwzględnia przesuwaną granicę wieku emerytalnego wprowadzoną na mocy ustawy z dnia 11 maja 2012 r. o zmianie ustawy o emeryturach i rentach z Fun-

rządzące. Platforma Obywatelska, sprawująca władzę w latach 2007-2015, wprowadziła od 1 stycznia 2013 r. sukcesywne podwyższanie granicy wieku emerytalnego do 67. roku życia dla obu płci, a w listopadzie $2016 \mathrm{r}$. rząd Prawa i Sprawiedliwości przywrócił poprzednie granice tego wieku, zróżnicowane dla obu płci (tj. 60 lat dla kobiet oraz 65 lat dla mężczyzn), które weszły w życie od 1 października $2017 \mathrm{r}$.

2 Rocznik Demograficzny 2016, GUS, Warszawa 2016, s. 72.

3 E. Kryńska, E. Kwiatkowski, Podstawy wiedzy o rynku pracy, Łódź 2013, s. 68.

4 Zob. szerzej: Prognoza Ludności na lata 2014-2050, „Studia i Analizy Statystyczne”, Warszawa 2014 r., s. 147; Rocznik Demograficzny 2016..., s. 168-169. 
duszu Ubezpieczeń Społecznych oraz niektórych innych ustaw ${ }^{5}$, przyjmując tym samym dla kolejnych lat prognozy „ruchomą” górną granicę wieku produkcyjnego (jednocześnie dolną dla wieku poprodukcyjnego) wynoszącą: dla mężczyzn - 67 lat (w latach 2020-2050), a dla kobiet - 62 lata w 2020 r., 63,25 roku w 2025 r., 64,5 roku w 2030 r., 65,75 w 2035 r. oraz 67 lat w latach 2040-2050.

Analiza przewidywanych zmian demograficznych w Polsce w latach 2013-2050 wskazuje, że w wypadku obu wariantów granic wieku produkcyjnego wystąpią następujące tendencje dotyczące potencjalnych zasobów pracy:

- ubytek potencjalnych zasobów pracy,

- starzenie się tych zasobów,

- wzrost obciążenia demograficznego ludności w wieku produkcyjnym ludnością $\mathrm{w}$ wieku nieprodukcyjnym.

Przyjęte warianty kształtowania się granic wieku produkcyjnego będą miały natomiast istotny wpływ na skalę i intensywność przebiegu tych tendencji oraz ich „rozłożenie” w czasie.

Określając przewidywany ubytek potencjalnych zasobów pracy, należy zauważyć, że większa skala tego ubytku pojawi się w wypadku przyjęcia tradycyjnych granic wieku produkcyjnego (wariant I). Dla tego wariantu przewiduje się, że w latach 2013-2050 populacja osób w wieku zdolności do pracy zmniejszy się o blisko $8 \mathrm{mln}$ osób (tj. z 24,4 mln do 16,5 mln osób), jej udział w ogólnej liczbie ludności zaś obniży się o 14,6\% (tj. z 63,4\% do 48,8\%) - vide tabela 1. Łagodniejsza skala ubytku analizowanych zasobów, szacowana na około 5,5 mln osób (tj. z 24,5 mln do 19 mln osób), przewidywana jest dla II wariantu granic wieku produkcyjnego, uwzględniającego tzw. ruchomy wiek przejścia na emeryturę. Gdyby zatem utrzymano wprowadzone w 2013 r. stopniowe podwyższanie wieku emerytalnego, to w porównaniu z I wariantem prognozy zasób ludności w wieku produkcyjnym byłby w 2050 r. większy o 2,5 mln osób. Niższy byłby też spadek udziału potencjalnych zasobów pracy w ogólnej liczbie ludności, gdyż obniżyłby się on o 7,7 punktów procentowych (z 63,8\% w 2013 do 56,1\% w 2050 r.), wobec spadku aż o 14,6 punktów procentowych w przypadku I wariantu prognozy - tabela 1 .

Tabela 1. Przewidywany ubytek potencjalnych zasobów pracy w Polsce w latach 2013-2050

\begin{tabular}{l|c|c|c|c|c}
\hline \multicolumn{1}{c|}{ Wyszczególnienie } & 2013 & 2020 & 2035 & 2050 & $2013-2050$ \\
\hline \multicolumn{5}{c}{ WARIANT I wieku produkcyjnego } \\
\hline $\begin{array}{l}\text { Liczba ludności w wieku } \\
\text { produkcyjnym (w tys.) }\end{array}$ & 24422 & 22787 & 20715 & 16583 & -7839 \\
\hline $\begin{array}{l}\text { Udział w ogólnej liczbie ludności } \\
(\text { w \%) }\end{array}$ & 63,4 & 59,7 & 56,8 & 48,8 &. \\
\hline
\end{tabular}

5 Dz.U. z 2012 r. Nr 0 poz. 637. 
WARIANT II wieku produkcyjnego

\begin{tabular}{l|c|c|c|c|c}
\hline $\begin{array}{l}\text { Liczba ludności w wieku } \\
\text { produkcyjnym (w tys.) }\end{array}$ & 24548 & 23820 & 22569 & 19048 & -5464 \\
\hline $\begin{array}{l}\text { Udział w ogólnej liczbie ludności } \\
(\mathrm{w} \%)\end{array}$ & 63,8 & 62,5 & 61,9 & 56,1 &. \\
\hline
\end{tabular}

Źródło: Prognoza Ludności na lata 2014-2050, „Studia i Analizy Statystyczne”, Warszawa 2014 r., s. 111 i 148.

Przyjęte w prognozie demograficznej warianty wieku produkcyjnego wpływają też na różnice $\mathrm{w}$ rozkładzie czasowym przewidywanych zmian rozmiarów potencjalnych zasobów pracy. Obliczenia wskazują, że w wypadku każdego z tych wariantów największego ubytku zasobów, wynoszącego blisko $3 \mathrm{mln}$ osób, należy spodziewać się w ostatniej dekadzie horyzontu prognozy, tj. w latach 2040-2050. Należy jednak zauważyć, że proces zmniejszania się liczebności osób $\mathrm{w}$ wieku zdolności do pracy, rozpoczęty po 2010 r., trwa i dotyczyć będzie każdej z dekad okresu prognostycznego ${ }^{6}$. W pierwszych dekadach tego okresu (tj. do 2040 r.) będzie on również znacząco odczuwalny. W każdej z tych dekad analizowana populacja skurczy się średnio o około 1,5 mln osób w przypadku I wariantu lub o około 800 tys. osób w przypadku wariantu II — vide tabela 2.

Tabela 2. Przewidywane ubytki potencjalnych zasobów pracy w przekroju czasowym w Polsce w latach 2013-2050

\begin{tabular}{|c|c|c|c|c|c|}
\hline Wyszczególnienie & 2013 & 2020 & 2030 & 2040 & 2050 \\
\hline \multicolumn{6}{|c|}{ Wariant I } \\
\hline $\begin{array}{l}\text { Liczba ludności w wieku } \\
\text { produkcyjnym, w tys. }\end{array}$ & 24422,1 & 22787,6 & 21504,1 & 19536,1 & 16582,7 \\
\hline $\begin{array}{l}\text { Ubytek/ przyrost, w stosunku } \\
\text { do okresu poprzedniego, w tys. }\end{array}$ & $\mathrm{x}$ & $-1634,5$ & $-1283,5$ & -1968 & $-2953,4$ \\
\hline \multicolumn{6}{|c|}{ Wariant II } \\
\hline $\begin{array}{l}\text { Liczba ludności w wieku } \\
\text { produkcyjnym, w tys. }\end{array}$ & 24548,1 & 23820,0 & 22894,7 & 22005,2 & 19047,7 \\
\hline $\begin{array}{l}\text { Ubytek/ przyrost, w stosunku } \\
\text { do okresu poprzedniego, w tys. }\end{array}$ & $\mathrm{x}$ & $-728,1$ & $-925,3$ & $-889,5$ & $-2957,5$ \\
\hline
\end{tabular}

Źródło: Rocznik Demograficzny 2016, GUS, Warszawa 2016, s. 168-169.

${ }^{6}$ W latach 2010-2015 liczba ludności w wieku produkcyjnym zmniejszyła się o blisko 830 tys. osób, jej odsetek zaś o 2 punkty procentowe (z 64,4\% do 62,4\%). Obserwowana zmiana wynika z procesu przesuwania się do grupy wieku poprodukcyjnego licznych roczników osób urodzonych w pierwszej połowie lat pięćdziesiątych XX w. Zob. Podstawowe informacje o rozwoju demograficznym Polski do 2014 r. Notatka informacyjna GUS z 27 stycznia 2015, s. 16; Rocznik Demograficzny 2016..., s. 58-61, 161. 
Zmiany w populacji potencjalnych zasobów pracy będą dotyczyć nie tylko sukcesywnego ubytku tych zasobów, ale także przekształceń struktury wiekowej tej grupy, w tym relacji ilościowych pomiędzy ludnością $\mathrm{w}$ wieku produkcyjnym mobilnym (18-44 lat) a ludnością $\mathrm{w}$ wieku produkcyjnym niemobilnym (od 45 lat do przyjętej, zróżnicowanej wariantowo, górnej granicy wieku produkcyjnego). Analiza danych prognostycznych wskazuje na kontynuację w najbliższych dekadach rozpoczętego już wcześniej, w latach 90. $\mathrm{XX}$ w., procesu starzenia się potencjalnych zasobów pracy ${ }^{7}$. Zwraca się uwagę, że proces ten będzie wynikiem przede wszystkim dużego ubytku ludności w wieku produkcyjnym mobilnym, w mniejszym zaś stopniu skutkiem zmian ilościowych dotyczących ludności $\mathrm{w}$ wieku produkcyjnym niemobilnym — vide tabela 3. Szacuje się, że w latach 2013-2050 populacja ludności w wieku 18-44 lata zmniejszy się o około 6 mln osób (w obu wariantach prognozy), a jej udział w ogólnych zasobach pracy obniży się o 6,5 punktów procentowych (tj. z 62,8\% do 56,3\%) w wypadku I wariantu wieku produkcyjnego lub o 13,5 punktów procentowych (tj. z 62,5\% do 49\%) w przypadku wariantu II. W przeciwieństwie do zasobów pracy w wieku mobilnym, których rozmiary, w obu wariantach prognozy, będą się systematycznie kurczyć, zmiany liczebności osób w wieku produkcyjnym niemobilnym będą zróżnicowane $\mathrm{w}$ zależności od przyjętych górnych granic wieku produkcyjnego. W wypadku I wariantu granic wieku produkcyjnego liczba ludności w wieku niemobilnym, po naprzemiennych okresach spadków i wzrostów, będzie w 2050 r. o 1,8 mln niższa w porównaniu z 2013 r., zaś jej udział w ogólnych rozmiarach potencjalnych zasobów pracy zwiększy się o 6,5 punktów procentowych (z 37,2\% do 43,7\%). W wypadku przyjęcia ruchomych granic wieku produkcyjnego (wariant II prognozy) proces starzenia się zasobów pracy będzie bardziej intensywny. Przyczyni się do tego nie tylko ubytek ludności w wieku mobilnym, lecz także duży przyrost w pierwszych dekadach okresu prognostycznego (tj. do 2035 r.) liczby osób w wieku produkcyjnym niemobilnym — szacowany na około 2,6 mln. Pomimo przewidywanego pod koniec horyzontu czasowego prognozy spadku liczebności tej populacji będzie ona w $2050 \mathrm{r}$ o o 0,5 mln większa w porównaniu z $2013 \mathrm{r}$., jej udział w ogólnych rozmiarach potencjalnych zasobów pracy wyniesie zaś $51 \%$ i będzie znacznie wyższy (bo o ponad 7 punktów procentowych) w porównaniu z szacunkami dla I wariantu wieku produkcyjnego - vide tabela 3.

Tabela 3. Prognoza struktury wiekowej potencjalnych zasobów pracy w Polsce w latach 2013-2050

\begin{tabular}{l|c|c|c|c|c|c|c|c|c|c}
\hline $\begin{array}{c}\text { Ludność } \\
\text { w wieku: }\end{array}$ & 2013 & 2020 & 2035 & 2050 & $2013-2050$ & 2013 & 2020 & 2035 & 2050 & $2013-2050$ \\
\hline \multicolumn{7}{c}{ Wariant I } & Wariant II \\
\hline $\begin{array}{l}\text { produkcyjnym } \\
\text { mobilnym } \\
(18-44)\end{array}$ & 15338 & 14219 & 10725 & 9331 & -6007 & 15338 & $\begin{array}{c}14 \\
219\end{array}$ & 10725 & 9331 & -6007 \\
\hline
\end{tabular}

7 Zob. szerzej: K. Sipurzyńska-Rudnicka, Uwarunkowania demograficzne i edukacyjne sytuacji na polskim rynku pracy w latach 1990-2013, [w:] Współczesny rynek pracy. Zatrudnienie i bezrobocie w XXI wieku, red. M. Makuch, Wrocław 2014, s. 86. 


\begin{tabular}{l|c|c|c|c|c|c|c|c|c|c|c}
\hline $\begin{array}{l}\text { produkcyjnym } \\
\text { niemobilnym }\end{array}$ & 9084 & 8568 & 9990 & 7252 & -1832 & 9210 & 9601 & 11844 & 9717 & 507 \\
\hline $\begin{array}{l}\text { produkcyjnym } \\
\text { ogółem }\end{array}$ & 100 & 100 & 100 & 100 & $\cdot$ & 100 & 100 & 100 & 100 & $\cdot$ \\
\hline $\begin{array}{l}\text { produkcyjnym } \\
\text { mobilnym } \\
(18-44)\end{array}$ & 62,8 & 62,4 & 51,8 & 56,3 & $\cdot$ & 62,5 & 59,7 & 47,5 & 49,0 & $\cdot$ \\
\hline $\begin{array}{l}\text { produkcyjnym } \\
\text { niemobilnym }\end{array}$ & 37,2 & 37,6 & 48,2 & 43,7 &. & 37,5 & 40,3 & 52,5 & 51,0 &. \\
\hline
\end{tabular}

Źródło: Prognoza Ludności..., s. 111 i 148.

Dla przyszłości rynku pracy i gospodarki istotne znaczenie będzie miało nie tylko kurczenie się potencjalnych zasobów pracy oraz ich starzenie się, lecz także przewidywane relacje ilościowe pomiędzy tymi zasobami a pozostałymi subpopulacjami wieku ekonomicznego (tj. ludnością w wieku przedprodukcyjnym oraz poprodukcyjnym) określane przez współczynnik obciążenia demograficznego ${ }^{8}$. Całkowite obciążenie potencjalnych zasobów pracy ludnością w wieku nieprodukcyjnym będzie rosło dynamiczniej i osiągnie wyższy poziom w wypadku utrzymania tradycyjnych granic wieku produkcyjnego (wariant I). Szacowany współczynnik obciążenia demograficznego dla tego wariantu wyniesie w 2050 r. 105 osób na 100 osób w wieku produkcyjnym — tabela 4 . Jego wartość będzie niemal dwukrotnie wyższa w porównaniu z rokiem wyjściowym prognozy (tj. 2013 r.), kiedy wynosił on 58 osób na 100 osób w wieku produkcyjnym.

Tabela 4. Obciążenie demograficzne potencjalnych zasobów pracy w Polsce w latach 2013-2050

\begin{tabular}{|c|c|c|c|c|c|c|c|c|c|c|}
\hline \multirow{3}{*}{ Wyszczególnienie } & 2013 & 2020 & 2030 & 2040 & 2050 & 2013 & 2020 & 2030 & 2040 & 2050 \\
\hline & \multicolumn{5}{|c|}{ I wariant wieku produkcyjnego } & \multicolumn{5}{|c|}{ II wariant wieku produkcyjnego } \\
\hline & \multicolumn{10}{|c|}{ Liczba osób na 100 osób w wieku produkcyjnym } \\
\hline $\begin{array}{l}\text { Całkowite obciążenie } \\
\text { demograficzne }\end{array}$ & 58 & 67 & 73 & 83 & 105 & 57 & 60 & 62 & 62 & 78 \\
\hline $\begin{array}{l}\text { Obciążenie } \\
\text { ludnością w wieku } \\
\text { poprodukcyjnym }\end{array}$ & 29 & 38 & 45 & 56 & 75 & 28 & 32 & 37 & 38 & 52 \\
\hline
\end{tabular}

Źródło: Rocznik Demograficzny 2016..., s. 168-169; Prognoza Ludności..., s. 148 i 150.

Przewiduje się, że w całym okresie prognozy (2013-2050) niewielkim zmianom ulegać będzie obciążenie dziećmi i młodzieżą w wieku 0-17 (wahające się od 27 do 30 osób

${ }^{8}$ Całkowity współczynnik obciążenia demograficznego wskazuje na to, ile osób w wieku nieprodukcyjnym (tj. przedprodukcyjnym i poprodukcyjnym łącznie) przypada na 100 osób w wieku produkcyjnym. Współczynnik ten prezentowany jest często w rozbiciu na dwie składowe, z których jedna określa liczbę osób w wieku przedprodukcyjnym (0-17 lat) na 100 osób w wieku produkcyjnym (obciążenie ludnością w wieku nieprodukcyjnym), a druga - liczbę osób w wieku poprodukcyjnym na 100 osób w wieku produkcyjnym (obciążenie ludnością w wieku poprodukcyjnym). Zob. Rocznik Demograficzny 2016..., s. 24 i 59. 
na 100 osób w wieku produkcyjnym w wypadku I wariantu prognozy lub od 24 do 28 osób na 100 osób w wieku produkcyjnym w wypadku II wariantu prognozy). Wzrost całkowitego współczynnika obciążenia demograficznego będzie zatem rezultatem przede wszystkim rosnącego obciążenia potencjalnych zasobów pracy ludnością w wieku poprodukcyjnym. Prognozowany znaczny przyrost ludności w wieku emerytalnym spowoduje sukcesywny wzrost obciążenia tą populacją z 29 do 75 osób na 100 osób w wieku produkcyjnym (tj. ponad dwuipółkrotny) w wypadku I wariantu prognozy lub z 28 do 52 osób na 100 osób w wieku produkcyjnym (tj. blisko dwukrotny) w wypadku II wariantu prognozy.

\section{Zagrożenia wynikające z przewidywanych zmian rozmiarów i struktury potencjalnych zasobów pracy w Polsce}

Przewidywane w Polsce zmiany demograficzne stanowić będą istotne uwarunkowanie rozwoju sytuacji na rynku pracy, możliwości rozwojowych gospodarki oraz kierunków działań w ramach szeroko rozumianej polityki społeczno-gospodarczej. Duży ubytek potencjalnych zasobów pracy, intensywne starzenie się tych zasobów oraz znaczny wzrost wskaźnika obciążenia demograficznego mogą stać się źródłem wielu różnych zagrożeń. Do najważniejszych zaliczyć można:

a) zagrożenia związane z ubytkiem potencjalnych zasobów pracy:

— deficyt siły roboczej i trudności w zaspokajaniu potrzeb kadrowych zakładów pracy,

— osłabienie atrakcyjności inwestycyjnej naszej gospodarki z powodu słabszego dostępu do czynnika ludzkiego,

- obniżenie wzrostu PKB;

b) zagrożenia związane ze starzeniem się potencjalnych zasobów pracy:

- usztywnienie rynku pracy po stronie podażowej,

- ograniczona absorpcja nowych technik i technologii,

— zwiększone koszty prowadzenia działalności gospodarczej wynikające ze starzenia się zasobów kadrowych przedsiębiorstw,

c) zagrożenia związane ze wzrostem współczynnika obciążenia demograficznego:

- wzrost wydatków publicznych na świadczenia społeczne,

- wzrost obciążeń podatkowych i parapodatkowych osób pracujących i pracodawców,

- skłonność do działania w szarej strefie.

Istotnym wyzwaniem dla rynku pracy może być już sam ubytek potencjalnych zasobów pracy. W najbliższych dziesięcioleciach należy się liczyć z możliwością pojawienia się i utrwalania na polskim rynku pracy typu nierównowagi odmiennego od bezrobocia, jakim jest deficyt siły roboczej. Niedobór podaży pracy, zwłaszcza w sytuacji dobrej koniunktury gospodarczej, może spowodować, że część pracodawców będzie miała problemy z zaspokajaniem potrzeb kadrowych i zmuszona będzie ograniczyć działalność gospodarczą. W skali całego kraju sytuacja taka osłabi wzrost gospodarczy. Jedna z projekcji kształtowania się liczby ludności aktywnej zawodowo w Polsce, przygotowana 
przez Komisję Europejską - wskazująca na uwarunkowany procesami demograficznymi spadek liczby osób aktywnych zawodowo o blisko 6 mln osób w latach 2010-2060 przestrzega, że zmiany te mogą już od 2015 r. obniżać wzrost potencjalnego PKB w naszym kraju od 0,7 do 1,5 punktów procentowych w relacji rok do roku ${ }^{9}$. Zastanawiając się nad wpływem prognozowanych zamian demograficznych na przyszłe rozmiary podaży pracy, warto przytoczyć wyniki badań i symulacji przeprowadzonych przez Pawła A. Strzeleckiego. Autor analizował to, jaki wpływ na zmiany podaży pracy w przyszłości miałyby alternatywne założenia dotyczące czterech czynników (rozwiązań), tj.: wzrostu dzietności, wydłużenia okresu aktywności zawodowej poprzez podnoszenie wieku emerytalnego, podnoszenia współczynników aktywności zawodowej ludności, a także wzrostu migracji zastępczych. Wyniki tych symulacji wskazują, że zapowiadane zmiany demograficzne w Polsce będą tak głębokie, iż w średnim i dłuższym okresie (ponad 20 lat) żadne $z$ wymienionych rozwiązań, zastosowane samodzielnie, nie rozwiąże problemu kurczących się zasobów pracy. Z tego też względu uzasadnione jest opracowanie rozwiązań łączących wszystkie zaproponowane koncepcje, co mogłoby doprowadzić do zahamowania dramatycznych zmian podaży pracy w bliższej i dalszej przyszłości ${ }^{10}$.

Liczne ograniczenia i zagrożenia dla gospodarki i rynku pracy mogą wynikać z intensywnego starzenia się potencjalnych zasobów pracy. Elżbieta Kryńska wskazuje na następujące bezpośrednie skutki starzenia się tej populacji ${ }^{11}$ :

- Ograniczona mobilność pracownicza zasobów pracy i związane z tym ryzyko usztywnienia rynku pracy. Pracownicy w starszych grupach wiekowych na ogół charakteryzują się niższą mobilnością (zawodową, edukacyjną, przestrzenną i międzyzakładową), co wpływa na zmniejszenie ich zdolności do elastycznego reagowania na zmiany zachodzące w gospodarce i na rynku pracy.

- Ograniczona absorpcja nowych technik i technologii wytwarzania, zmniejszenie innowacyjności pracowników, a w konsekwencji osłabienie konkurencyjności gospodarki i jej zdolności do rywalizacji na światowych rynkach.

- Zagrożenie słabnącej wraz z wiekiem produktywności, wzmacniane przez zagrożenie pogarszania się stanu zdrowia i zwiększonej absencji chorobowej pracowników starszych mogą powodować wzrost kosztów pracy. Ponadto dostosowanie starzejących się pracowników do tempa bieżących zmian techniczno-technologicznych będzie wymagało ciągłego uzupełniania ich kwalifikacji zawodowych, co pociągnie za sobą koszty szkoleń i przestojów w pracy.

- Większa skłonność pracowników starszych do stałej lub okresowej dezaktywizacji zawodowej, zwłaszcza jeśli będzie ona powiązana z możliwością korzystania z różnych świadczeń społecznych (np. rent, emerytur). Będzie to wywierać presję na pracodawcach do większego niż dotychczas liczenia się z oczekiwaniami pracowników w zakresie warunków pracy, czasu pracy oraz płacy.

9 P.A. Strzelecki, Czy Polska jest skazana na spadek podaży pracy w przyszłości?, „Zeszyty Naukowe” Instytutu Statystyki i Demografii SGH, 2012, nr 24, s. 2.

10 Ibidem.

11 E. Kryńska, Wpływ zmian demograficznych na rynek pracy — aspekty gospodarcze, „Biuletyn Rządowej Rady Ludnościowej” 2010, nr 55, s. 35-36. 
Starzenie się zasobów pracy będzie wyzwaniem dla różnych dziedzin całokształtu polityki społeczno-gospodarczej. Dotyczyć to będzie między innymi dostosowania programów i usług służb zatrudnienia do potrzeb bezrobotnych 50+ (polityka rynku pracy), rozwoju różnych form kształcenia ustawicznego, rozwijających i uzupełniających kwalifikacje coraz liczniejszej rzeszy starszych pracobiorców (polityka edukacyjna), dostosowania do zmian demograficznych rozwiązań w zakresie ubezpieczeń emerytalnych i rentowych (ubezpieczenia społeczne), dostosowania świadczeń zdrowotnych oraz organizacji służby zdrowia do potrzeb coraz bardziej starzejących się zasobów ludzkich (polityka ochrony zdrowia), rozwoju różnych form instytucjonalnej i pozainstytucjonalnej opieki nad ludźmi starszymi (m.in. w sferze pomocy społecznej) $)^{12}$.

Z punktu widzenia sytuacji gospodarczej, w tym sytuacji na rynku pracy, ważna jest analiza zmian relacji pomiędzy grupami wieku ekonomicznego. Należy tu bowiem podkreślić, że relacje ilościowe pomiędzy ludnością $\mathrm{w}$ wieku produkcyjnym a ludnością w wieku nieprodukcyjnym niosą określone konsekwencje w sferze finansów publicznych dla systemów zabezpieczenia społecznego, rynku pracy i polityki państwa na rynku pracy. Szczególnie niekorzystny jest wzrost obciążenia potencjalnych zasobów pracy ludnością w wieku poprodukcyjnym. Wiąże się z nim bowiem wzrost wydatków publicznych na świadczenia społeczne (emerytalne, rentowe, zdrowotne i inne), wzrost obciążeń podatkowych i parapodatkowych osób pracujących i pracodawców, ograniczenie wzrostu lub wręcz spadek liczby miejsc pracy wynikający z rosnących kosztów, zmniejszenie konkurencyjności firm, skłonność do wchodzenia w szarą sferę, rozwój nielegalnego zatrudnienia lub wzrost emigracji zarobkowej ${ }^{13}$.

\section{Złożoność dotychczasowych związków pomiędzy demografią a sytuacją na rynku pracy ostrzeżeniem przed zbyt uproszczonymi wnioskami dotyczącymi przyszłości}

Zarysowane potencjalne zagrożenia dla gospodarki i rynku pracy, wynikające z prognozowanych zmian demograficznych, skłaniają do zastanowienia się nad tym, na ile są one realne oraz jak rozwijać się będzie rzeczywista sytuacja na polskim rynku pracy. Odpowiedź na to pytanie jest niezwykle trudna z uwagi na złożoność uwarunkowań i czynników oddziałujących na rynek pracy. Procesy demograficzne są tylko jednym z nich i już choćby $z$ tego powodu nie muszą być rozstrzygające dla gospodarki.

Eksperci wskazują, że przewidywane zmiany demograficzne skłaniać będą przede wszystkim do bardziej racjonalnego wykorzystania dostępnych w kraju zasobów siły roboczej między innymi poprzez rozszerzenie zatrudniania grup dotychczas słabiej wykorzystywanych na rynku pracy, tj. kobiet, młodzieży, osób niepełnosprawnych, osób $\mathrm{w}$ wieku poprodukcyjnym czy też bezrobotnych ${ }^{14}$. Oprócz tego wymuszą też, wcześniej

12 K. Sipurzyńska-Rudnicka, op. cit., s. 86.

13 Zob. szerzej E. Kryńska, Wplyw zmian..., s. 34

14 Zob. A. Skórska, Uwarunkowania demograficzne, [w:] Ekonomia rynku pracy, red. D. Kotlorz, Katowice 2007, s. 79-80. 
czy później, realizację wielu reform usprawniających polski rynek pracy i jego otoczenie, co w dłuższym okresie podniesie atrakcyjność tego rynku i sprzyjać może napływowi rąk do pracy (w ramach reemigracji Polaków lub w ramach migracji zastępczej obcych zasobów pracy) ${ }^{15}$. Z analizy danych statystycznych wynika, że w Polsce są wciąż znaczne rezerwy siły roboczej, po które można sięgnąć w najbliższych latach. Obejmują one między innymi blisko 5,5 mln osób biernych zawodowo w wieku produkcyjnym (1859/64 lat) lub 7,6 mln biernych zawodowo w wieku produkcyjnym wg definicji Eurostat $(15-64 \text { lat })^{16}$. Tak duże rozmiary tej populacji powiązane są $\mathrm{z}$ wciąż niskimi w naszym kraju wskaźnikami zatrudnienia kobiet (45,5\%), młodzieży (tj. 28,9\% dla wieku 15-24 lat oraz 49,2\% dla wieku 20-24 lat), niepełnosprawnych (14,1\%), osób w wieku okołoemerytalnym (47,5\% dla wieku 55-64 lat) czy też ludności w wieku poprodukcyjnym 60-65 lat i więcej $(8,1 \%)^{17}$. Zaprezentowane wskaźniki obrazują duże obszary niewykorzystanego jak dotąd potencjału ludzkiego. Do rezerw siły roboczej w najbliższym okresie zaliczyć też można wciąż znaczące zasoby bezrobotnych, tj. 1,3 mln osób według rejestrów urzędów pracy ${ }^{18}$ lub 0,9 mln według BAEL. Zarysowane rezerwy czynnika ludzkiego w Polsce pozwalają przypuszczać, że w najbliższych latach nasz rynek pracy nie powinien szczególnie boleśnie odczuwać deficytu siły roboczej i związanych z tym skutków. Tym bardziej, że wśród działań mających na celu amortyzowanie obserwowanego ubytku potencjalnych zasobów pracy obserwuje się rozszerzanie migracji zastępczej, tj. napływ imigrantów zarobkowych z innych państw, głównie z Europy Wschodniej. Warto w tym miejscu podkreślić, że w 2016 r. liczba oświadczeń o zamiarze powierzenia pracy cudzoziemcowi, zarejestrowanych przez powiatowe urzędy pracy, wyniosła 1,3 mln i była siedmiokrotnie wyższa w porównaniu z $2008 \mathrm{r} .{ }^{19}$ Szacuje się, że wśród cudzoziemców pracujących obecnie w Polsce zdecydowaną większość stanowią obywatele Ukrainy, których w 2016 r. było ok. 1,26 mln osób (tj. 96\% ogółu pracujących cudzoziemców). Nie bez znaczenia dla określenia rezerw siły roboczej w najbliższych latach jest też duża liczebność polskich czasowych emigrantów zagranicznych, kształtująca się w latach 2010-2015 na poziomie 2,0-2,4 mln osób ${ }^{20}$. W wypadku tej grupy pojawia się jednak pytanie o możliwą skalę reemigracji i powrotów tej ludności do Polski.

$\mathrm{W}$ rozważaniach na temat wpływu przewidywanych zmian demograficznych na gospodarkę i rynek pracy w dłuższej perspektywie czasowej należy zachować większą ostrożność. Dotychczasowe statystyki społeczno-demograficzne wskazują bowiem na złożoność zależności między zmianami demograficznymi a rynkiem pracy czy też w szerszym ujęciu pomiędzy demografią a gospodarką. Tym samym przestrzegają przed zbyt

15 Zob. C. Żołędowski, Migracje zarobkowe w czasie kryzysu, [w:] Polityka społeczna w kryzysie, red. M. Księżopolski, B. Rysz-Kowalczyk, C. Żołędowski, Warszawa 2009, s. 178.

16 Stan na IV kwartał 2016 r. Zob. szerzej: Monitoring Rynku Pracy. Kwartalna informacja o rynku pracy, Opracowanie sygnalne GUS, Warszawa, 23 lutego 2017 r., s. 14.

17 Ibidem, s. 7-8.

18 Bezrobocie rejestrowane. I-IV kwartał 2016 r., GUS, Warszawa 2017, s. 13.

19 Informacja nt. zatrudniania cudzoziemców w Polsce (grudzień 2016 r.), Ministerstwo Rodziny, Pracy i Polityki Społecznej, Departament Rynku Pracy, 30 grudnia 2016 r.

${ }^{20}$ Informacja o rozmiarach $i$ kierunkach czasowej emigracji z Polski w latach 2004-2015. Notatka Informacyjna GUS, Warszawa, 5 maja 2016 r., s. 3. 
uproszczonymi wnioskami na ten temat. Praktyka pokazuje, że przyrosty lub ubytki zasobów ludzkich, w tym potencjalnych zasobów pracy, nie muszą przekładać się na odpowiadające im przyrosty lub ubytki liczby pracujących. Podobną złożoność obserwuje się w wypadku wzrostu gospodarczego, poziom którego nie musi być bezpośrednio powiązany ze wzrostem lub spadkiem rozmiarów zasobów ludzkich czy też ze wzrostem lub spadkiem liczby pracujących. Jednym z przykładów złożonych zależności pomiędzy demografią a wzrostem gospodarczym są zmiany obserwowane w USA. W latach 1870-2016 liczba ludności tego kraju wzrosła z $40 \mathrm{mln}$ do $323 \mathrm{mln}$, a zatem ośmiokrotnie. W tym samym czasie wzrost PKB na 1 mieszkańca wzrósł z 3000\$ do 56084\$, tj. dziewiętnastokrotnie $^{21}$. Przyrost PKB był zatem znacznie szybszy od wzrostu liczby ludności.

Złożoność relacji pomiędzy rozmiarami potencjalnych zasobów pracy a rynkiem pracy i gospodarką obrazuje też sytuacja obserwowana w ostatnich dekadach w Polsce. W latach 1992-2010 (tj. w okresie znacznego przyrostu potencjalnych zasobów pracy) pomimo dużego wzrostu liczby ludności w wieku produkcyjnym, bo o blisko $2,4 \mathrm{mln}$ osób, liczebność pracujących wyraźnie się zmniejszyła - aż o ponad 1,2 mln osób w świetle sprawozdawczości podmiotów gospodarczych lub nieznacznie tylko wzrosła, gdyż o 400 tys. w świetle Badania Aktywności Ekonomicznej Ludności - vide tabela 5. Z kolei w latach 2010-2015 (tj. w okresie ubytku potencjalnych zasobów pracy) pomimo spadku o ponad 800 tys. liczby ludności w wieku produkcyjnym, liczebność pracujących wzrosła o 723 tys. osób - zarówno według BAEL, jak i w świetle sprawozdawczości podmiotów gospodarczych - vide tabela 6 .

Tabela 5. Przyrost potencjalnych zasobów pracy a liczba pracujących w Polsce, w latach 1992-2010

\begin{tabular}{l|c|c|c}
\hline \multirow{2}{*}{ Wyszczególnienie } & 1992 & 2010 & $\begin{array}{c}\text { Przyrost/ubytek } \\
1992-2010\end{array}$ \\
\cline { 2 - 4 } & \multicolumn{2}{|c}{ w tys. } \\
\hline Liczba ludności w wieku produkcyjnym (18-59/64) & 22458 & 24831 & +2373 \\
\hline Liczba pracujących według BAEL & 15135 & 15557 & +422 \\
\hline $\begin{array}{l}\text { Liczba pracujących według sprawozdawczości } \\
\text { podmiotów gospodarki narodowej }\end{array}$ & 15357 & 14107 & -1250 \\
\hline
\end{tabular}

Źródło: Rocznik Statystyczny Rzeczypospolitej Polskiej 2016, GUS, Warszawa 2016, s. 42-43; Polska 1989-2014, GUS, Warszawa 2014, s. 14-15; Aktywność ekonomiczna ludności. IV kwartat 2015, GUS, Warszawa 2016, s. 35-38; Rocznik Demograficzny 2007, GUS, Warszawa 2007; Bank Danych Lokalnych GUS.

21 Zob. szerzej: E. Mączyńska, Przełom cywilizacyjny a wzrost gospodarczy. Niedocenione aspekty demograficzne, „Biuletyn Rządowej Rady Ludnościowej” 2010, nr 55, s. 18. 
Tabela 6. Ubytek potencjalnych zasobów pracy a liczba pracujących w Polsce w latach 2010-2015

\begin{tabular}{l|c|c|c}
\hline \multirow{2}{*}{ Wyszczególnienie } & 2010 & 2015 & $\begin{array}{c}\text { Przyrost/ubytek } \\
1992-2010\end{array}$ \\
\cline { 2 - 4 } & \multicolumn{3}{|c}{ w tys. } \\
\hline Liczba ludności w wieku produkcyjnym (18-59/64) & 24831 & 24002 & -829 \\
\hline Liczba pracujących według BAEL & 15557 & 16280 & +723 \\
\hline $\begin{array}{l}\text { Liczba pracujących według sprawozdawczości } \\
\text { podmiotów gospodarki narodowej }\end{array}$ & 14107 & 14830 & +723 \\
\hline
\end{tabular}

Źródło: Rocznik Statystyczny Rzeczypospolitej Polskiej 2016..., s. 42-43; Polska 1989-2014..., s. 14-15; Aktywność ekonomiczna ludności. IV kwartał 2015..., s. 35-38; Rocznik Demograficzny 2007...; Bank Danych Lokalnych GUS.

Szukając przyczyn dotychczasowego charakteru relacji pomiędzy liczbą pracujących a liczbą osób w wieku produkcyjnym w Polsce w okresie po 1989 r., warto uwzględnić charakter powiązań ilościowych, jakie w tym okresie wystąpiły pomiędzy dynamiką liczby pracujących a dynamiką PKB. Z analizy danych statystycznych wynika, że w Polsce na przestrzeni dwudziestu lat (1995-2015) PKB per capita wzrósł blisko trzyipółkrotnie, tj. z $7583 \$$ amerykańskich do 26261 amerykańskich, podczas gdy liczba pracujących wzrosła w tym czasie zaledwie o 8,7\% — vide tabela 7 . Znaczny wzrost gospodarczy nie przełożył się zatem na duży wzrost zapotrzebowania na siłę roboczą. Warto przy tym zauważyć, że tak duża asymetria pomiędzy dynamiką PKB a dynamiką liczby pracujących była jedną z najwyższych w Europie. Tylko w kilku krajach europejskich, głównie Europy Wschodniej (Litwa, Łotwa, Rumunia, Rosja), była ona wyższa niż w naszym kraju. Większość pozostałych państw europejskich charakteryzowała się wyższym przyrostem pracujących przy słabszej dynamice PKB. Dla przykładu, w Niemczech liczba pracujących wzrosła o 12,4\%, podczas gdy PKB per capita wzrósł dwukrotnie - tabela 7.

Tabela 7. Liczba pracujących a PKB na 1 mieszkańca, w Polsce na tle świata i innych państw w latach 1995-2015

\begin{tabular}{|c|c|c|c|c|c|c|}
\hline \multirow{2}{*}{ Kraj } & \multicolumn{2}{|c|}{$\begin{array}{c}\text { Liczba pracujących } \\
\text { (w tys.) }\end{array}$} & \multicolumn{2}{|c|}{$\begin{array}{l}\text { PKB na } 1 \text { mieszkańca } \\
\text { (w \$ amerykańskich) }\end{array}$} & \multirow{2}{*}{$\begin{array}{c}\text { Przyrost/ } \\
\text { ubytek } \\
\text { pracujących } \\
1995=100\end{array}$} & \multirow[t]{2}{*}{$\begin{array}{c}\text { Przyrost/ } \\
\text { ubytek PKB } \\
1995=100\end{array}$} \\
\hline & 1995 & 2015 & 1995 & 2015 & & \\
\hline Polska & 14791 & 16084 & 7583 & 26261 & 108,7 & 346,3 \\
\hline Litwa & 1632 & 1335 & 6180 & 27680 & 81,8 & 447,9 \\
\hline Łotwa & 949 & 896 & 5964 & 24257 & 94,4 & 406,7 \\
\hline Rumunia & 11152 & 8535 & 5704 & 21403 & 76,5 & 375,2 \\
\hline
\end{tabular}




\begin{tabular}{l|r|r|r|r|r|c}
\hline Rosja & 64149 & 72324 & 5612 & 24451 & 112,7 & 435,7 \\
\hline Austria & 3675 & 4148 & 23706 & 48194 & 112,9 & 203,3 \\
\hline Belgia & 3793 & 4552 & 22871 & 44093 & 120,0 & 192,8 \\
\hline Dania & 2601 & 2752 & 23352 & 46624 & 105,8 & 199,7 \\
\hline Francja & 21907 & 26424 & 20686 & 39631 & 120,6 & 191,6 \\
\hline Holandia & 6782 & 8319 & 22963 & 48313 & 122,7 & 210,4 \\
\hline Niemcy & 35782 & 40211 & 23094 & 47377 & 112,4 & 205,1 \\
\hline Norwegia & 2043 & 2641 & 24075 & 61197 & 129,3 & 254,2 \\
\hline USA & 124900 & 148834 & 28782 & 56116 & 119,2 & 195,0 \\
\hline Szwajcaria & 3748 & 4600 & 28953 & 61086 & 122,7 & 211,0 \\
\hline Szwecja & 4051 & 4837 & 22752 & 46704 & 119,4 & 205,3 \\
\hline Wlk. Brytania & 25989 & 31205 & 22490 & 41459 & 120,1 & 184,3 \\
\hline Świat & 2417 & 3213 & 6438 & 15546 & 132,9 & 241,5 \\
\hline
\end{tabular}

Źródło: statystyka międzynarodowa GUS, http://stat.gov.pl/statystyka-miedzynarodowa (dostęp: 6 kwietnia 2017).

Zaobserwowane złożone powiązania pomiędzy zmianami demograficznymi a sytuacją na rynku pracy, czy też w szerszym ujęciu pomiędzy demografią a gospodarką, przestrzegają przed zbyt uproszczonymi wnioskami na ten temat, zwłaszcza dotyczącymi przyszłości.

Elżbieta Mączyńska zwraca uwagę na to, że między demografią a wzrostem gospodarczym i sytuacją na rynku pracy występują złożone sprzężenia zwrotne, które nie poddają się prostej ocenie ilościowej. Rezultaty tych powiązań uzależnione są bowiem od wielu czynników - zarówno ilościowych (ilość i struktura wiekowa ludności, struktura wykształcenia, współczynniki aktywności zawodowej ludności, poziom inwestycji, poziom konsumpcji), jak i jakościowych (np. jakość edukacji, kształcenia i kwalifikacji; czynniki kulturowe, polityczne itp.), przy czym wśród czynników jakościowych rozstrzygające znaczenie ma polityka gospodarcza, a ona $\mathrm{z}$ kolei jest pochodną przyjętych rozwiązań kształtujących ramy ustroju społeczno-gospodarczego ${ }^{22}$. Warto w tym miejscu podkreślić, że czynnik demograficzny określa przede wszystkim rozmiary podaży pracy, natomiast stopień zagospodarowania tej podaży wynika głównie z poziomu rozwoju strony popytowej rynku pracy oraz czynników określających rozmiary popytu na pracę, w tym głownie takich czynników pierwotnych, jak: popyt na wytwarzane dobra i usługi, wydajność pracy, czas pracy oraz poziom płac realnych ${ }^{23}$. Każdy z tych czynników jest uwarunkowany wieloma innymi czynnikami natury ekonomicznej, techniczno-technologicznej, kulturowej, instytucjonalno-prawnej czy politycznej. Demografia nie musi zatem przesądzać o sytuacji

\footnotetext{
22 Ibidem.

23 J. Unolt, Ekonomiczne problemy rynku pracy, Katowice 1999, s. 30-31.
} 
na przyszłym rynku pracy i charakterze nierównowagi na tym rynku, gdyż jak zauważa w rozważaniach na ten temat Janina Jóźwiak, „[t]rudno przewidzieć jakie zmiany na rynku pracy (choćby z powodu rozwoju technologii) nastąpią w najbliższych pięciu dekadach" ${ }^{24}$.

\section{Podsumowanie}

Prognozy wskazują na bardzo głębokie w najbliższych dekadach (do 2050 r.) przemiany demograficzne w Polsce. W zakresie potencjalnych zasobów pracy przewidywany jest znaczny ubytek tych zasobów, starzenie się populacji oraz wzrost obciążenia tych zasobów ludnością w wieku nieprodukcyjnym. Skala i intensywność tych zmian zależeć będą głównie od przyjętych granic wieku produkcyjnego. Zapowiadane tendencje mogą stać się istotnym zagrożeniem dla gospodarki i rynku pracy. Negatywne skutki gospodarcze i rynkowe przewidywanych zmian demograficznych nie są jednak przesądzone. Demografia nie jest bowiem jedynym uwarunkowaniem sytuacji na rynku pracy. Złożone powiązania i relacje pomiędzy zmianami demograficznymi a sytuacją na rynku pracy, czy też w szerszym ujęciu pomiędzy demografią a gospodarką, zaobserwowane w ostatnich dekadach w Polsce i innych krajach, skłaniają do zachowania dużej ostrożności w formułowaniu wniosków dotyczących kształtowania się tych relacji w przyszłości. Warto w tym miejscu podkreślić, że czynnik demograficzny określa głównie rozmiary podaży pracy, natomiast stopień zagospodarowania tej podaży wynika głównie z poziomu rozwoju strony popytowej rynku pracy oraz czynników określających rozmiary zapotrzebowania na siłę roboczą, w tym z postępu techniczno-technologicznego.

\section{Bibliografia}

Aktywność ekonomiczna ludności. IV kwartał 2015, GUS, Warszawa 2016.

Bezrobocie rejestrowane. I-IV kwartat 2016 r., GUS, Warszawa 2017.

Informacja nt. zatrudniania cudzoziemców w Polsce (grudzień 2016 r.), Ministerstwo Rodziny, Pracy i Polityki Społecznej, Departament Rynku Pracy, 30 grudnia 2016 r.

Informacja o rozmiarach $i$ kierunkach czasowej emigracji $z$ Polski w latach 2004-2015. Notatka informacyjna z 5 maja 2016 r., GUS, Warszawa.

Jóźwiak J., Demograficzne uwarunkowania rynku pracy w Polsce, [w:] Rynek pracy wobec zmian demograficznych, red. M. Kiełkowska, „Zeszyty Demograficzne” nr 1, Instytut Obywatelski, Warszawa 2013.

Kryńska E., Wpływ zmian demograficznych na rynek pracy - aspekty gospodarcze, „Biuletyn Rządowej Rady Ludnościowej", 2010, nr 55.

Kryńska E., Kwiatkowski E., Podstawy wiedzy o rynku pracy, Wydawnictwo UŁ, Łódź 2013.

Mączyńska E., Przełom cywilizacyjny a wzrost gospodarczy. Niedocenione aspekty demograficzne, „Biuletyn Rządowej Rady Ludnościowej”, 2010, nr 55.

Monitoring Rynku Pracy. Kwartalna informacja o rynku pracy, Opracowanie sygnalne GUS, Warszawa, 23 lutego $2017 \mathrm{r}$.

24 J. Jóźwiak, Demograficzne uwarunkowania rynku pracy w Polsce, [w:] Rynek pracy wobec zmian demograficznych, red. M. Kiełkowska, „Zeszyty Demograficzne” nr 1, Warszawa 2013, s. 22. 
Podstawowe informacje o rozwoju demograficznym Polski do 2014 r. Notatka informacyjna GUS z 27 stycznia 2015.

Polska 1989-2014, GUS, Warszawa, 2014.

Prognoza Ludności na lata 2014-2050, GUS, Warszawa 2014.

Rocznik Demograficzny 2007, GUS, Warszawa 2007.

Rocznik Demograficzny 2016, GUS, Warszawa 2016.

Rocznik Statystyczny Rzeczypospolitej Polskiej 2016, GUS, Warszawa, 2016.

Sipurzyńska-Rudnicka K., Uwarunkowania demograficzne i edukacyjne sytuacji na polskim rynku pracy w latach 1990-2013, [w:] Współczesny rynek pracy. Zatrudnienie i bezrobocie w XXI wieku, red. M. Makuch, Wydawnictwo CEdu Sp. z o.o., Wrocław 2014.

Skórska A., Uwarunkowania demograficzne, [w:] Ekonomia rynku pracy, red. D. Kotlorz, Wydawnictwo AE w Katowicach, Katowice 2007.

Strzelecki P.A., Czy Polska jest skazana na spadek podaży pracy w przyszłości?, „Zeszyty Naukowe” Instytutu Statystyki i Demografii SGH, 2012, nr 24.

Unolt J., Ekonomiczne problemy rynku pracy, Wydawnictwo Śląsk, Katowice 1999.

Żołędowski C., Migracje zarobkowe w czasie kryzysu, [w:] Polityka społeczna w kryzysie, red. M. Księżopolski, B. Rysz-Kowalczyk, C. Żołędowski, Oficyna Wydawnicza ASPRA-JR, Warszawa 2009.

\section{The demographic future of Poland and the labour market}

Keywords: demography, labour market, labour resources, Poland, forecasts

\section{Summary}

The study focuses on the demographic changes expected in Poland by 2050 and their impact on the labour market. The forecasts indicate a significant loss of potential labour resources, their aging and the increase in the burden on those resources from the non-productive population. This situation may trigger a number of threats to the labour market and the economy, including the occurrence of labour shortages, weakening of competitiveness and economic growth. Previous socio-demographic statistics, however, point to the complexity of the relationship between demography and the labour market, and they discourage simplistic conclusions regarding the nature of these links in the future. 